\title{
EVALUATING THE ECOLOGICAL RESILIENT DRIVEN PERFORMANCE OF A TROPICAL WASTE STABILIZATION POND SYSTEM USING ECOLOGICAL SIGNATURE OF BIOLOGICAL INTEGRITY
}

\author{
Susmita Lahiri Ganguly' ${ }^{1}$ Dipanwita Sarkar Paria', B.B. Jana' \\ 1 International Centre for Ecological Engineering and Department of Environmental Management, University \\ of Kalyani, Kalyani-741 235, West Bengal, India, e-mail: bbj_icee@yahoo.co.in
}

Received: 2015.04.12

Accepted: 2015.06.02

Published: 2015.07.01

\begin{abstract}
Using ecological signature of biological integrity as a measure of performance, the reclamation efficiency of waste stabilization ponds was evaluated over a period of four years in a tropical sewage treatment plant - cum fish culture consisting of two anaerobic, two facultative and four maturation ponds located serially across the sewage effluent gradient. The four maturation ponds were used for batch culture of fish. Samples of surface and bottom water as well as surface sediment were collected twice a month from different ponds of the system and examined for some nutrient cycling bacteria, primary production, chlorophyll content of micro-algae, phytoplankton, zooplankton abundance, fish growth and water quality parameters. Computation of ecological signature using aerobic mineralization index for heterotrophic and ammonifying bacteria revealed steady increase across the sewage effluent gradient. The heterotrophic and ammonifying bacterial populations appeared to have a direct function with the concentrations of chemical oxygen demand of water. The sum of total scores for different optimal conditions for fish growth increased as a function of the distance from the source of effluent implying that ecological resilience of the waste stabilization ponds has been accomplished by the sedimentation, chelation, and biological functional attributes mediated through redundancy of different subsystems, self- purification capacity of the system as a whole.
\end{abstract}

Keywords: ecological signature, biological integrity, nutrient cycling bacteria, microalgae, ecological resilience, waste-stabilization-pond.

\section{INTRODUCTION}

Resilience, related to self organized behaviour of the ecosystems over time and space, is regulated by keystone structuring process as well as redundancy behaviour of species. Species may appear to perform the same function under a restricted set of conditions, yet their functional roles may vary in a natural heterogenous environments [Wellnitz and LeRoy Poff, 2001]. Cardinale et al. [2000] has nicely modelled how spatial heterogeneity interacts with temporal disturbance to modify the relationship between species diversity and ecosystem productivity. As a rule, ecosystem stability is achieved through holism which is a fully interactive network between living and non living envi- ronment; the holistic effect is always larger than the sum of all the elements comprising the ecosystem. While maintaining a capacity for renewal in a dynamic environment, it provides an ecological buffer that protects the system from the failure of management actions [Gunderson, 2000]. It is further documented that the bacterial functional redundancy may be a useful indicator of soil quality and ecosystem functioning [Yin et al., 2000]. This phenomenon is well depicted in a waste stabilization pond which is characterized by the dominant assemblages of primary producers or rooted macrophytes, grazing pressure and physical disturbances include light and temperature [Holling, 1973; Ludwig et al., 1996; Weaver et al., 1996] or excessive nutrient loading that causing eutrophication. 
The waste stabilization ponds (WSPs) are large, shallow basins in which primary treated sewage is further treated mimicking nature's own biological processes as mechanism involving bacteria-algae- heterotroph complex in a coordinated, interdependent and interactive way for enhancing the resilience of the ecosystem. The high performance, low cost, low energy (often zero energy) have made WSPs an ecological complement to traditional wastewater treatment since it does not require any external energy or chemical input; sun is the only source of energy and hence, it is sustainable [Karlsson et al., 2011]. The temperature and duration of sunlight in tropical countries offer an excellent opportunity for removal of pathogens from wastewater. A modified sewage stabilization pond system using two facultative ponds has been used for reducing the construction and maintenance costs [Alcocer et al., 1993]. The same was true for the existing system under study.

Ecological resilience of the waste stabilization ponds is accomplished by the heterogenous assemblages of autotroph- heterotroph- microbes including nutrient cycling bacteria that played a pivotal role in the degradation of organic matter and hence regulate the water quality criteria of waste stabilization ponds [Ganguly, 2002]. It is likely that nutrient cycling bacteria that grown in eutrophic or wastewater system might have adapted to luxuriant storage of nutrients in excess of their requirement, and hence may contribute to the nutrient dynamics and wastewater reclamation. For example, some phosphorus sequestering bacteria capable of utilizing their intracellular storage molecule of polyphosphate to control phosphate availability in the environment have been isolated from wastewater [McMahon and Read, 2013]. It is also reported that wastewater effluent impacts ammonia-oxidizing prokaryotes of the Grand River, Canada [Sonthiphand et al., 2013].

Ecological signature of biological integrity representing the holism with sum of the total functional attributes shared by different components of ecosystem comprising primary subsystem, secondary subsystem, microbial subsystem or detrital subsystem would be an useful tool for assessing the performance of the dynamic waste stabilization pond system having the characteristics of an ecotone with both lentic and lotic environments. Hardly any data is available about the assessment of performance of waste stabilization ponds especially in tropical countries using ecological signature of biological integrity.
Because of solar energy and nutrient enrichment driven massive algal bloom, waste stabilization ponds provide an excellent opportunity for examining the carbon sequestration potential of micro-algae in relation to ecological cum nutrient cycling bacterial resilience along the sewage effluent gradient. In practice, atmospheric carbon utilized by the micro-algae via photosynthesis may be quantified in terms of primary productivity which, in turn, was influenced by the interdependent activities of organic matter and nutrient cycling bacteria resulting in spatial and seasonal variability in terms of diversity and abundance of planktonic community, water quality and fish growth. The purpose of this study was to evaluate the resilient driven reclamation performance of domestic wastewater using the ecological signature of biological integrity.

\section{METHODS}

The study was conducted in a Sewage Treatment System (STS) located in a moderately populated (around 100 000) township of Kalyani, West Bengal, India. Out of 17 mld (million litre per day) of sewage discharged every day, 11 mld of sewage is treated biologically by passing the effluent through the waste stabilization pond system consisting of two anaerobic ponds $(26 \times 52 \times 2.5 \mathrm{~m})$, two facultative ponds $(64 \times 150 \times 1.5 \mathrm{~m})$ and four maturation ponds $(52 \times 156 \times 1 \mathrm{~m})$ that are placed serially across the sewage effluent gradient (Figure 1). Two anaerobic ponds were connected with two facultative ponds via inlets. Likewise, the facultative ponds in their turn were connected with the first maturation pond which was again connected with the remaining three maturation ponds via their outlets placed diagonally to each other. The distance covered from the source to the final discharge point was nearly $826 \mathrm{~m}$, with an average retention time of $1-2$ days in anaerobic ponds, 4-8 days in facultative ponds and 2-5 days in maturation ponds. Hence, the total retention time was between 7 and 15 days. The average flow rate of wastewater is $2 \times 10^{6} 1$ per day and the water flow is regulated through a sluice gate installed at the junction of anaerobic and facultative ponds. In the downstream, four maturation ponds (MPs) with diluted sewage after retention of about 7-15 days after achieving the standard water quality were used for batch culture of Indian carps. Four maturation ponds were used for the four months with 


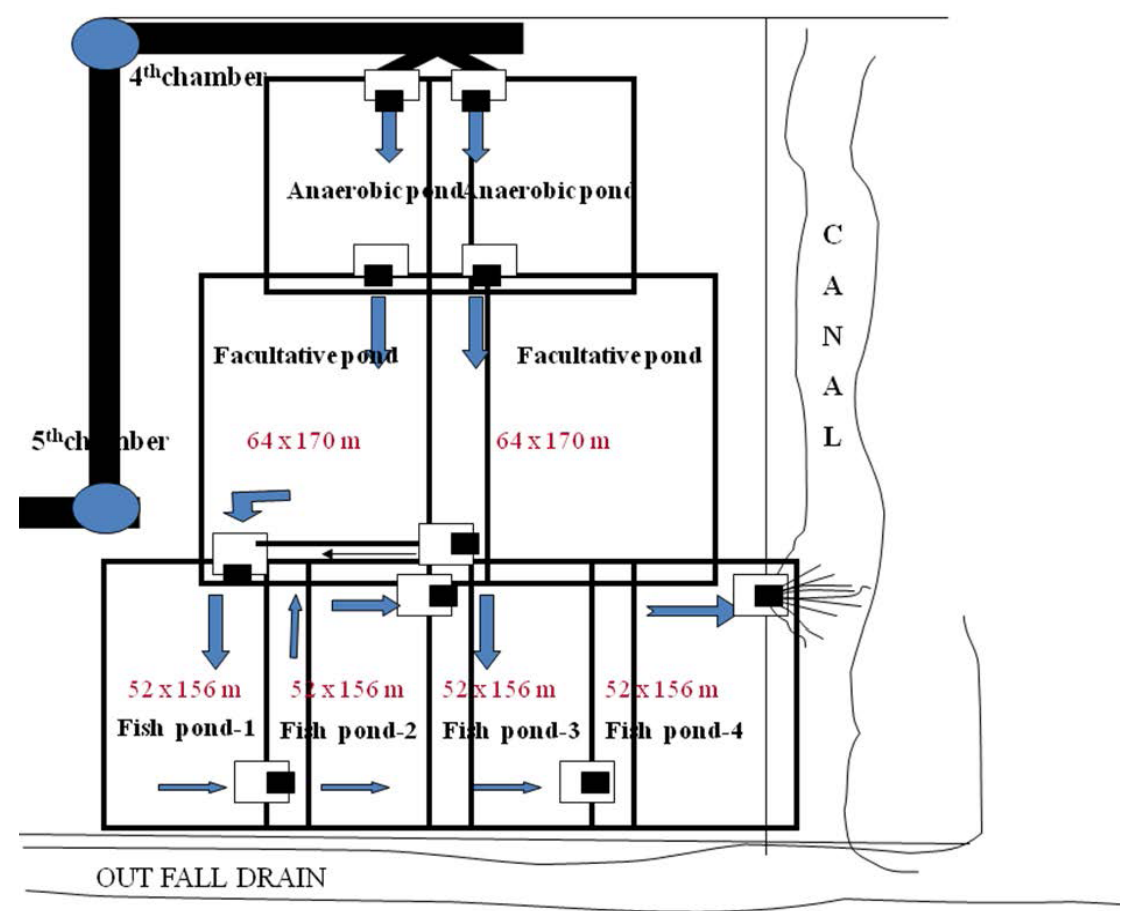

Figure 1. Schematic diagram of sewage water fish farm in Kalyani

three production cycles in a year following the practices of multiple stocking and multiple harvesting. The final effluents were then discharged into the adjoining river system Ganges.

The study was conducted for four years in two phases each of two years duration. The first phase of investigation conducted during the period of 1998-2000 dealt with spatial and seasonal distribution of some major nutrient cycling bacteria of water and sediment related to the physicochemical milieu and the second one (2003-2005) was concerned with the assessment of primary productivity of micro-algae (phytoplankton), zooplankton abundance and fish growth in maturation ponds related to water quality. Samples of surface and bottom water as well from surface sediments were collected every fortnight from selected sites of each pond during the period of investigation for enumeration of different nutritional groups of bacteria (Atlas and Bartha, 1998) as well as for analysis of water quality and nutrient quality parameters following the standard methods (Wetzel and Likens, 1991; Jackson, 1970; and APHA, 1998). The sampling sites selected were the inlet of the facultative pond (FP), first, second, third and fourth maturation ponds (MP-1, MP-2, MP-3 and MP-4).

For measurement of primary productivity of phytoplankton, samples of surface water were collected in triplicate from each pond and determined following the dark and light bottle method [Vollenweider, 1974]. Samples of surface water were collected in a bucket taken from different places of each sampling station and then mixed for the estimation of chlorophyll a content of total phytoplankton. The qualitative and quantitative estimation of zooplankton population were made according to the method described in APHA [1998]. The results of quantitative data phytoplankton was subjected to computation of the diversity indices following the standard methods [Odum, 1996]. Fishes reared in four maturation ponds were harvested every four months of batch culture and their growth data were evaluated. The mean of each parameter obtained from 48 samples during the period of two years in each phase was used in the study.

\section{ECOLOGICAL SIGNATURE OF BIOLOGICAL INTEGRITY}

The ecological signature of biological integrity was used as a tool for measuring the performance of engineering resilient waste stabilization pond systems across the sewage effluent gradient and was assessed considering the following parameters.

\section{Sediment Respiration $\left(S R_{D O}\right)$}

The state of sediment respiration in different ponds of WSPs was based on the fact that the depletion of dissolved oxygen in bottom water 
(mud-water interface) relative to surface water was due to its utilization for degradation and mineralization of accumulated organic matter in the bottom sediment at the time of measurement, and that was clearly reflected in the difference of dissolved oxygen content of water between surface and bottom layer. The sediment respiration $(S R)$ was calculated as:

$$
S R_{D O}=D O_{\mathrm{BW} \mathrm{or} \mathrm{SW}}-D O_{\mathrm{BW} / \text { or SW } /}
$$

organic matter content in sediment or water $\times 100$.

\section{Aerobic Mineralization Index $\left(A M_{i}\right)$}

Since the decomposition and degradation of organic matter accumulated in the bottom sediment was primarily performed by heterotrophic bacteria using oxygen as electron acceptor from the mud water interface, the Aerobic Mineralization Index $\left(A M_{i}\right)$ was calculated as:

$$
A M_{i}=\frac{D O_{c n}}{H B_{c n}} \times 100
$$

where: $D O_{c n}-$ mean concentration of DO of surface water or bottom water, $H B_{c n}$ - mean counts of $\mathrm{HB}$ in water or bottom sediment.

\section{Resilience Performance of WSPs}

The overall assessment of the performance of engineering resilient WSPs was done by calculating the frequency distribution of the optimal values for different parameters $(\mathrm{pH}$, dissolved oxygen, phosphate, ammonium- $\mathrm{N}$, nitrate- $\mathrm{N}$ and fish yield) considered most important for maintaining ecological buffer for ecosystem health and fish culture in maturation ponds. The score values were obtained on the basis of number of occurrence of the optimal values of that parameter in a particular fish growing pond with respect to value occurred in other ponds investigated. Finally, the total scores for all the parameters were obtained by summing up these values for a particular pond system. The total score values were then compared among the investigated ponds for assessment of resilient driven reclamation efficiency.

All the data were statistically evaluated. Oneway analysis of variance using the statistically package (SPSS) was used to find the differences in the response between ponds located along the sewage effluent gradient. Level of statistical significance was accepted at $\mathrm{P}<0.05$.

\section{RESULTS}

\section{Productivity of phytoplankton}

The values of gross primary productivity of phytoplankton (GPP), community respiration (CR), net primary productivity of phytoplankton (NPP) as well as chlorophyll content of microalgae were significantly higher $(\mathrm{P}<0.05)$ in the facultative ponds compared to maturation ponds (Table 1). The ratio between the gross primary photosynthesis to community respiration $(\mathrm{P} / \mathrm{R})$ ranged from 0.39 to 8.6 in facultative ponds and 0.73 to 20.24 in maturation ponds (Table 1 ). In terms of autotrophic production, the values remained more than unity in $69-73 \%$ and $91-100 \%$ cases of the total number of measurements in facultative and maturation ponds respectively.

Phytoplankton community was represented by altogether 28 species of micro-algae which were common in their distribution in facultative and maturation ponds though their relative abundance varied in across the effluent gradient.

Table 1. Range and mean $( \pm \mathrm{SE})$ of gross and net primary production as well as community respiration in different sewage fed ponds investigated. Each mean represents the data of 24 samples collected during the period of two years (2003-2005). (FP - Facultative Pond; MP-1 - Maturation pond-1; MP-2 - Maturation pond-2; MP-3 - Matu-

\begin{tabular}{|c|c|c|c|c|c|c|c|c|c|c|}
\hline \multirow{2}{*}{ Parameters } & \multicolumn{2}{|c|}{ FP } & \multicolumn{2}{|c|}{$\mathrm{MP}-1$} & \multicolumn{2}{|c|}{ MP-2 } & \multicolumn{2}{|c|}{ MP-3 } & \multicolumn{2}{|c|}{$\mathrm{MP}-4$} \\
\hline & Range & Mean \pm SE & Range & Mean \pm SE & Range & Mean \pm SE & Range & Mean \pm SE & Range & Mean \pm SE \\
\hline $\begin{array}{l}\text { Gross Primary } \\
\text { Production } \\
\left(\mathrm{g} \mathrm{C} \mathrm{m}^{-2} \mathrm{~d}^{-1}\right)\end{array}$ & $5.61-67.53$ & $26.22 \pm 2.4$ & $0.68-21.12$ & $6.92 \pm 0.71$ & $1.51-22.61$ & $7.74 \pm 0.78$ & $1.59-20.07$ & $7.28 \pm 0.7$ & $0.90-19.04$ & $6.01 \pm 0.6$ \\
\hline $\begin{array}{l}\text { Net Primary } \\
\text { Production } \\
\left(\mathrm{g} \mathrm{C} \mathrm{m}^{-2} \mathrm{~d}^{-1}\right)\end{array}$ & $1.65-44.6$ & $16.38 \pm 1.6$ & $0.49-17.32$ & $4.75 \pm 0.39$ & $0.86-15.24$ & $4.86 \pm 0.5$ & $1.03-12.6$ & $4.05 \pm 0.4$ & $0.51-11.43$ & $3.59 \pm 0.4$ \\
\hline $\begin{array}{l}\text { Community } \\
\text { Respiration } \\
\left(\mathrm{g} \mathrm{C} \mathrm{m}^{-2} \mathrm{~d}^{-1}\right)\end{array}$ & $1.27-24.81$ & $10.67 \pm 1.09$ & $0.1-7.09$ & $1.93 \pm 0.2$ & $0.6-8.55$ & $2.51 \pm 0.3$ & $0.21-9.63$ & $2.96 \pm 0.28$ & $0.15-7.61$ & $2.28 \pm 0.23$ \\
\hline $\mathrm{P} / \mathrm{R}$ & $0.39-8.6$ & 2.357 & $0.73-15.75$ & 3.724 & $1-6.14$ & 2.128 & $1-9.35$ & 1.921 & $1-20.24$ & 3.130 \\
\hline
\end{tabular}
ration pond-3; MP-4 - Maturation pond-4) 


\section{Nutrient cycling bacterial dynamics}

The counts of heterotrophic bacteria (HB), ammonifying bacteria $(\mathrm{AB})$, phosphate solubilizing bacteria (PSB) occurring in surface water, bottom water as well as in surface sediment (Table 2) tended to reduce across the waste stabilization system from the inlet of facultative to the last maturation pond. The percent of reduction from source to the outlet was quite high in case of HB (73-88\%) followed by AB or PSB (74-85\%) in surface water, bottom water and in surface sediment.

On the other hand, the counts of both ammonia oxidizing bacteria (AOB) and cellulose decomposing bacteria $(\mathrm{CDB})$ reduced from inlet to the outlet of the facultative pond and then increased to some extent in maturation ponds. The per cent of increase from facultative pond to last maturation pond was 42 to $65 \%$ and 2 to $21 \%$ in case of $\mathrm{AOB}$ and $\mathrm{CDB}$, respectively. Though the counts of denitrifying bacteria (DNB) were slightly reduced in surface water, there was heavy spurt in the sediment of last maturation pond indicating the impact of interactions.

\section{Water quality}

As a result of interactive ecological processes, a distinct gradient in the values of $\mathrm{pH}$, total alkalinity and dissolved oxygen of water occurred across the sewage effluent gradient from the inlet of the facultative pond to last maturation pond (Table 3). The concentrations of ammonium-N, nitrite- $\mathrm{N}$ and nitrate- $\mathrm{N}$ as well as phosphate were substantially higher in facultative pond than in maturation ponds. Likewise, the concentration of chemical oxygen demand of water tended to reduce from facultative pond to the last maturation

Table 2. Range and mean $( \pm \mathrm{SE})$ count of different bacterial population (HB - Heterotrophic Bacteria; $A B$ - Ammonifying bacteria; PSB - Phosphate Solubilizing Bacteria; CDB - Cellulose Decomposing Bacteria; AOB - Ammonia Oxidizing Bacteria; DNB - Denitrifying Bacteria) in surface water, bottom water and sediment of different sewage fed ponds investigated. Each mean represents the data of 24 samples collected during the period of two years (2003-2005/1998-2000). (FP - Facultative Pond; MP-1 Maturation pond-1; MP-2 - Maturation pond-2; MP-3 - Maturation pond-3; MP-4 - Maturation pond-4)

\begin{tabular}{|c|c|c|c|c|c|c|c|c|c|c|}
\hline \multirow{3}{*}{$\begin{array}{c}\text { Bacterial } \\
\text { population }\end{array}$} & \multicolumn{10}{|c|}{ Sites } \\
\hline & \multicolumn{2}{|c|}{ FP } & \multicolumn{2}{|c|}{ MP-1 } & \multicolumn{2}{|c|}{ MP-2 } & \multicolumn{2}{|c|}{ MP-3 } & \multicolumn{2}{|c|}{ MP-4 } \\
\hline & Range & Mean & Range & Mean & Range & Mean & Range & Mean & Range & Mean \\
\hline \multicolumn{11}{|c|}{ Surface water } \\
\hline $\mathrm{HB}\left(\mathrm{x} 10^{5} \mathrm{ml}^{-1}\right)$ & $2.27-480.25$ & $120.63 \pm 3.3$ & $1.42-179.35$ & $62.7 \pm 0.44$ & $1-67.5$ & $44.35 \pm 0.25$ & $0.8-106.5$ & $36.8 \pm 0.18$ & $0.447-52.12$ & $27.74 \pm 0.135$ \\
\hline $\mathrm{AB}\left(\mathrm{x} 10^{5} \mathrm{ml}^{-1}\right)$ & $1.825-164.25$ & $80.25 \pm 0.85$ & $1.25-113.75$ & $47.81 \pm 0.28$ & $0.50-103.5$ & $34.86 \pm 0.17$ & $0.346-74$ & $28.15 \pm 0.14$ & $0.351-53.5$ & $20.22 \pm 0.11$ \\
\hline $\operatorname{PSB}\left(\mathrm{x} 10^{2} \mathrm{ml}^{-1}\right)$ & $1.52-162.5$ & $59.6 \pm 0.48$ & $0.98-85.25$ & $36.7 \pm 0.185$ & $0.74-64.3$ & $26.64 \pm 0.16$ & $0.32-46.3$ & $21.6 \pm 0.12$ & $0.3-44.5$ & $15.11 \pm 0.008$ \\
\hline $\mathrm{CDB}\left(\mathrm{x} 10^{3} \mathrm{ml}^{-1}\right)$ & $0.802-72.5$ & $43.2 \pm 0.36$ & $0.67-76.5$ & $31.3 \pm 0.18$ & $0.73-67.23$ & $40.64 \pm 0.2$ & $2-87.5$ & $45.7 \pm 0.26$ & $0.83-95.75$ & $50.53 \pm 0.32$ \\
\hline $\operatorname{AOB}\left(\times 10^{5} \mathrm{ml}^{-1}\right)$ & $8.25-54.75$ & $34.04 \pm 0.3$ & $6.75-50.25$ & $25.7 \pm 0.12$ & $1.0-65.2$ & $39.4 \pm 0.21$ & $12.5-74.6$ & $47 \pm 0.28$ & $3.75-80$ & $56.23 \pm 0.38$ \\
\hline $\operatorname{DNB}\left(\times 10^{2} \mathrm{ml}^{-1}\right)$ & $4.1-63.25$ & $26.2 \pm 0.25$ & $5.4-50.37$ & $25.34 \pm 0.13$ & $1.7-70.4$ & $34.86 \pm 0.17$ & $7.75-64.1$ & $41.86 \pm 0.22$ & $9.35-96.75$ & $24 \pm 0.12$ \\
\hline \multicolumn{11}{|c|}{ Bottom water } \\
\hline $\mathrm{HB}\left(\mathrm{x} 10^{5} \mathrm{ml}^{-1}\right)$ & $7.2-1007.5$ & $210.3 \pm 9.52$ & $5-471.5$ & $131 \pm 4.6$ & $3.2-102$ & $95.08 \pm 1.2$ & 3-105.6 & $76.2 \pm 0.82$ & $2.6-76$ & $55.45 \pm 0.43$ \\
\hline $\mathrm{AB}\left(\mathrm{x} 10^{5} \mathrm{ml}^{-1}\right)$ & $6.27-557.3$ & $226.6 \pm 11.24$ & $3.75-262.85$ & $120 \pm 2.8$ & $1.9-174.8$ & $85.72 \pm 0.88$ & $1.9-156.8$ & $72 \pm 0.79$ & $1.67-128.5$ & $52 \pm 0.43$ \\
\hline $\operatorname{PSB}\left(\mathrm{x} 10^{2} \mathrm{ml}^{-1}\right)$ & $3.08-328$ & $121.22 \pm 3.5$ & $1.54-131.5$ & $65.9 \pm 0.54$ & $1.42-89.2$ & $36.5 \pm 0.32$ & $0.445-68.9$ & $29 \pm 0.26$ & $.48-44.45$ & $18.5 \pm 0.09$ \\
\hline CDB $\times 10^{3} \mathrm{ml}^{-1}$ & $2.275-140.6$ & $75.6 \pm 0.68$ & $1.31-97.5$ & $53.67 \pm 0.44$ & $1.46-113.5$ & $63.7 \pm 0.5$ & $2.6-136.85$ & $70.17 \pm 0.79$ & $2.9-150.35$ & $77.42 \pm 0.81$ \\
\hline $\mathrm{AOB} \times 10^{5} \mathrm{ml}^{-1}$ & $18.75-85.8$ & $57 \pm 0.6$ & $9.6-73.8$ & $44.2 \pm 0.38$ & $13.8-120.5$ & $68.5 \pm 0.78$ & 18.4-133.4 & $79 \pm 0.88$ & $17.85-145.2$ & $86 \pm 0.88$ \\
\hline $\mathrm{DNB} \times 10^{2} \mathrm{ml}^{-1}$ & $17.8-692$ & $165.8 \pm 4.8$ & $10.1-503.65$ & $109.67 \pm 0.86$ & $13.6-613$ & $150.73 \pm 4.6$ & $18.4-769$ & $183.2 \pm 7.4$ & 23.9-910.5 & $239.6 \pm 11.45$ \\
\hline \multicolumn{11}{|c|}{ Surface sediment } \\
\hline $\mathrm{HB}\left(\mathrm{x} 10^{6} \mathrm{~g}^{-1}\right)$ & $2-80.75$ & $49.2 \pm 0.41$ & $1.125-58.5$ & $31.22 \pm 0.28$ & $0.75-50.5$ & $25.06 \pm 0.22$ & $0.55-43$ & $21.53 \pm 0.19$ & $0.375-24.25$ & $5.64 \pm 0.003$ \\
\hline $\mathrm{AB}\left(\mathrm{x} 10^{6} \mathrm{~g}^{-1}\right)$ & $68.75-315$ & $207.35 \pm 9.8$ & $18.75-149$ & $90.6 \pm 0.89$ & $6-109$ & $60.2 \pm 0.5$ & $5-91.5$ & $46.23 \pm 0.34$ & $3.25-66.7$ & $30.26 \pm 0.25$ \\
\hline $\operatorname{PSB}\left(\mathrm{x} 10^{3} \mathrm{~g}^{-1}\right)$ & $5.57-43$ & $22.56 \pm 0.1$ & $1.68-16.35$ & $12.21 \pm 0.02$ & $0.83-11$ & $8.37 \pm 0.008$ & $0.7-9.5$ & $6.9 \pm 0.005$ & $0.56-6.85$ & $5.076 \pm 0.0025$ \\
\hline $\mathrm{CDB}\left(\mathrm{x} 10^{4} \mathrm{~g}^{-1}\right)$ & $16-60.75$ & $39.34 \pm 0.32$ & $10.25-43.75$ & $25.9 \pm 0.14$ & $14.2-54$ & $34 \pm 0.25$ & $16.5-61.5$ & $40.4 \pm 0.22$ & $17.15-75.75$ & $47.65 \pm 0.26$ \\
\hline $\mathrm{AOB}\left(\mathrm{x} 10^{6} \mathrm{~g}^{-1}\right)$ & $20-69.5$ & $46.5 \pm 0.35$ & $17.25-59.3$ & $34.17 \pm 0.26$ & $23-69.5$ & $48.2 \pm 0.37$ & $32-79$ & $57 \pm 0.42$ & $36.5-85.5$ & $66.3 \pm 0.55$ \\
\hline $\operatorname{DNB}\left(\mathrm{x} 10^{3} \mathrm{~g}^{-1}\right)$ & $1.12-14.5$ & $7.706 \pm 0.006$ & $3.1-17.5$ & $11.33 \pm 0.009$ & $7.5-33$ & $23 \pm 0.2$ & $13-48$ & $31.03 \pm 0.12$ & $19.2-68$ & $44 \pm 0.23$ \\
\hline
\end{tabular}


Table 3. Mean values $( \pm$ SE) of different water quality parameters examined over four years (1998-2000; 20032005) along the sewage effluent gradient. (FP - Facultative Pond; MP-1 - Maturation pond-1; MP-2 - Maturation pond-2; MP-3 - Maturation pond-3; MP-4 - Maturation pond-4)

\begin{tabular}{|c|c|c|c|c|c|}
\hline \multirow{3}{*}{ Water Quality parameters } & \multicolumn{5}{|c|}{ Ponds along the sewage effluent gradient } \\
\hline & \multicolumn{5}{|c|}{ 1998-2000 } \\
\hline & $\mathrm{FP}$ & $\mathrm{MP}-1$ & MP-2 & MP-3 & MP-4 \\
\hline Temperature $\left({ }^{\circ} \mathrm{C}\right)$ & 27.8 & 27.9 & 28.01 & 28.1 & 28.06 \\
\hline $\mathrm{pH}$ & $6.94-7.7$ & $7.2-8.0$ & $7.39-8.15$ & $7.47-8.1$ & $7.55-8.3$ \\
\hline Free $\mathrm{CO}_{2}\left(\mathrm{mg}^{-1}\right)$ & $109.0 \pm 4.75$ & $89.38 \pm 5.11$ & $75.3 \pm 4.12$ & $64.5 \pm 4.1$ & $52.2 \pm 3.58$ \\
\hline Total alkalinity $\left(\mathrm{mg}^{-1}\right)$ & $137.74 \pm 2.86$ & $156.7 \pm 3.2$ & $170.4 \pm 3.45$ & $176.53 \pm 3.48$ & $187.87 \pm 1.9$ \\
\hline Dissolved oxygen(mg-l) & $8.4 \pm 0.25$ & $8.5 \pm 0.295$ & $7.9 \pm 0.18$ & $7.84 \pm 0.252$ & $7.9 \pm 0.262$ \\
\hline Chemical oxygen demand (mg-l) & $322.37 \pm 11.2$ & $194.46 \pm 12.2$ & $149.25 \pm 9.8$ & $125.04 \pm 7.45$ & $93.21 \pm 5.63$ \\
\hline Orthophosphate $\left(\mathrm{mg}^{-1} \mathrm{l}\right)$ & $0.239 \pm 0.036$ & $0.1503 \pm 0.016$ & $0.1183 \pm 0.01$ & $0.0903 \pm 0.0083$ & $0.0577 \pm 0.05$ \\
\hline Soluble reactive phosphorus $\left(\mathrm{mg}^{-1}\right)$ & $0.194 \pm 0.01$ & $0.0968 \pm 0.006$ & $0.066 \pm 0.006$ & $0.051 \pm 0.0054$ & $0.0304 \pm 0.0034$ \\
\hline Ammonium-N (mg-l) & $1.813 \pm 0.095$ & $1.247 \pm 0.048$ & $0.947 \pm 0.02$ & $0.849 \pm 0.032$ & $0.632 \pm 0.034$ \\
\hline Nitrite-N (mg-1) & $0.202 \pm 0.032$ & $0.115 \pm 0.007$ & $0.073 \pm 0.003$ & $0.053 \pm 0.004$ & $0.035 \pm 0.003$ \\
\hline Nitrate-N (mg-l) & $0.229 \pm 0.21$ & $0.155 \pm 0.004$ & $0.123 \pm 0.004$ & $0.110 \pm 0.002$ & $0.092 \pm 0.001$ \\
\hline \multicolumn{6}{|c|}{$2003-2005$} \\
\hline Temperature $\left({ }^{\circ} \mathrm{C}\right)$ & 27.87 & 27.89 & 27.94 & 28.03 & 27.9 \\
\hline $\mathrm{pH}$ & $6-7.6$ & $6.93-7.7$ & $7.12-7.63$ & $7.15-7.85$ & $7.36-8$ \\
\hline Free $\mathrm{CO}_{2}\left(\mathrm{mg}^{-1}\right)$ & $104.3 \pm 4.17$ & $85.9 \pm 4.3$ & $75.5 \pm 4.2$ & $64.2 \pm 4.5$ & $48.9 \pm 3.3$ \\
\hline Total alkalinity $\left(\mathrm{mg}^{-1} \mathrm{l}\right)$ & $147.53 \pm 3.36$ & $161.7 \pm 3.5$ & $171.6 \pm 3.9$ & $177.88 \pm 3.6$ & $190.9 \pm 2.3$ \\
\hline Dissolved oxygen(mg-l) & $9.52 \pm 0.32$ & $7.74 \pm 0.23$ & $7.65 \pm 0.22$ & $7.67 \pm 0.235$ & $7.95 \pm 0.26$ \\
\hline Chemical oxygen demand (mg-l) & $265.31 \pm 10.49$ & $178.14 \pm 10.3$ & $148.56 \pm 10.02$ & $124.02 \pm 8.98$ & $79.04 \pm 6.12$ \\
\hline Orthophosphate $\left(\mathrm{mg}^{-1} \mathrm{l}\right)$ & $0.348 \pm 0.043$ & $0.202 \pm 0.02$ & $0.145 \pm 0.018$ & $0.121 \pm 0.016$ & $0.091 \pm 0.012$ \\
\hline Soluble reactive phosphorus $\left(\mathrm{mg}^{-1} \mathrm{l}\right)$ & $0.142 \pm 0.012$ & $0.0822 \pm 0.007$ & $0.0664 \pm 0.006$ & $0.05 \pm 0.005$ & $0.0242 \pm 0.003$ \\
\hline Ammonium-N (mg-1) & $4.382 \pm 0.472$ & $1.43 \pm 0.068$ & $1.2 \pm 0.060$ & $0.884 \pm 0.039$ & $0.525 \pm 0.026$ \\
\hline Nitrite-N (mg-l) & $0.428 \pm 0.055$ & $0.096 \pm 0.005$ & $0.073 \pm 0.004$ & $0.052 \pm 0.004$ & $0.029 \pm 0.002$ \\
\hline Nitrate-N (mg-l) & $0.39 \pm 0.380$ & $0.191 \pm 0.006$ & $0.191 \pm 0.007$ & $0.146 \pm 0.005$ & $0.124 \pm 0.003$ \\
\hline
\end{tabular}

pond suggesting the variations in spatial activity across the sewage effluent gradient. .

Comparison of mean values of nutrient parameters revealed less variability over the period of four years with the exception of facultative ponds where the concentration varied markedly (Figure 2). The concentration of dissolved oxygen in bottom water in different ponds was reduced by $14-48 \%$ over the values in surface water (Figure 3). The magnitude of difference was maximum (Figure 3 ) in case of facultative pond and minimum in last maturation pond; the ratio between the two showed gradual decline across the sewage effluent gradient

\section{Ecological signature of biological integrity}

Sediment respiration index was maximum in case of facultative pond (18\%), reduced to $13-14 \%$ in three maturation ponds, but increased slightly (16\%) in last maturation pond (Figure 4).
This shows that sediment respiration is primarily regulated by the algal driven oxygenation in the mud water interface. Further, degradation and subsequent mineralization of organic matter were found to increase gradually as a function of distance of sewage from its source.

The aerobic mineralization index $\left(\mathrm{AM}_{i}\right)$ for heterotrophic (HB) and ammonifying bacteria $(\mathrm{AB})$ as well as their mean counts (Figure 5) increased steadily across the pond systems exhibiting more than 4 fold increase in last maturation pond compared to facultative pond. The ratio between dissolved oxygen and ammonia oxidizing bacteria was maximum in case of maturation pond -1 followed by decline in the subsequent ponds investigated. On the other hand, the ratio of dissolved oxygen and denitrifying bacteria showed the opposite trend (Figure 6). As expected, the sum of the total population for heterotrophic and ammonifying bacteria was the direct function of the chemical oxygen demand of water in all the 


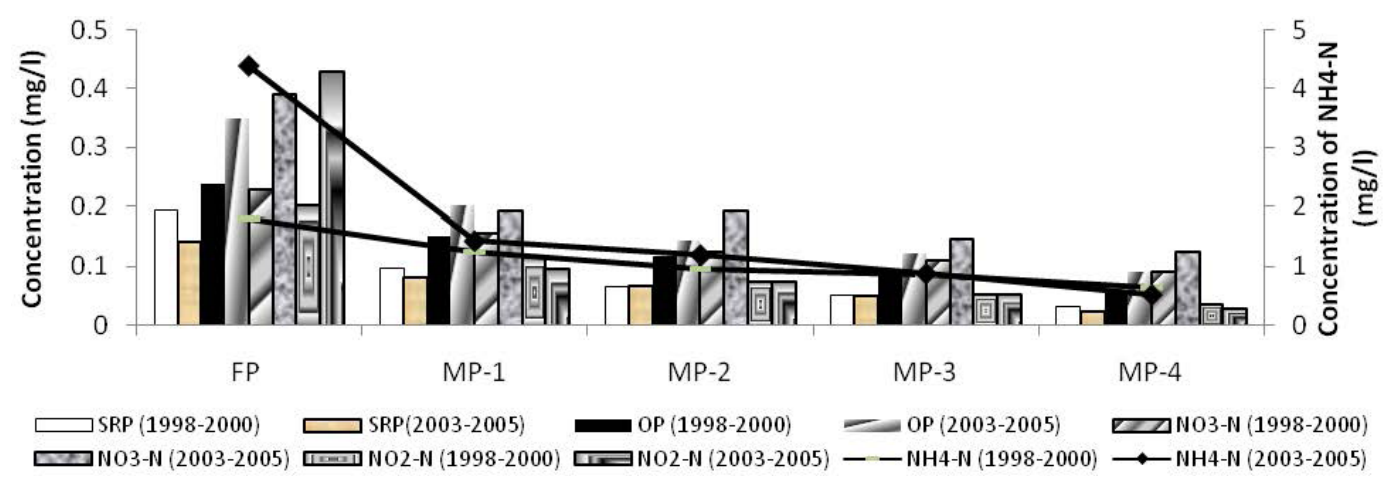

Figure 2. Comparison of the mean concentrations of ammonium- $\mathrm{N}\left(\mathrm{NH}_{4}-\mathrm{N}\right)$, nitrite- $\mathrm{N}\left(\mathrm{NO}_{2}-\mathrm{N}\right)$, nitrate- $\mathrm{N}$ $\left(\mathrm{NO}_{3}-\mathrm{N}\right)$, orthophosphate $(\mathrm{OP})$ and soluble reactive phosphorus (SRP) of different ponds between two phases (1998-2000 and 2003-2005) of investigation

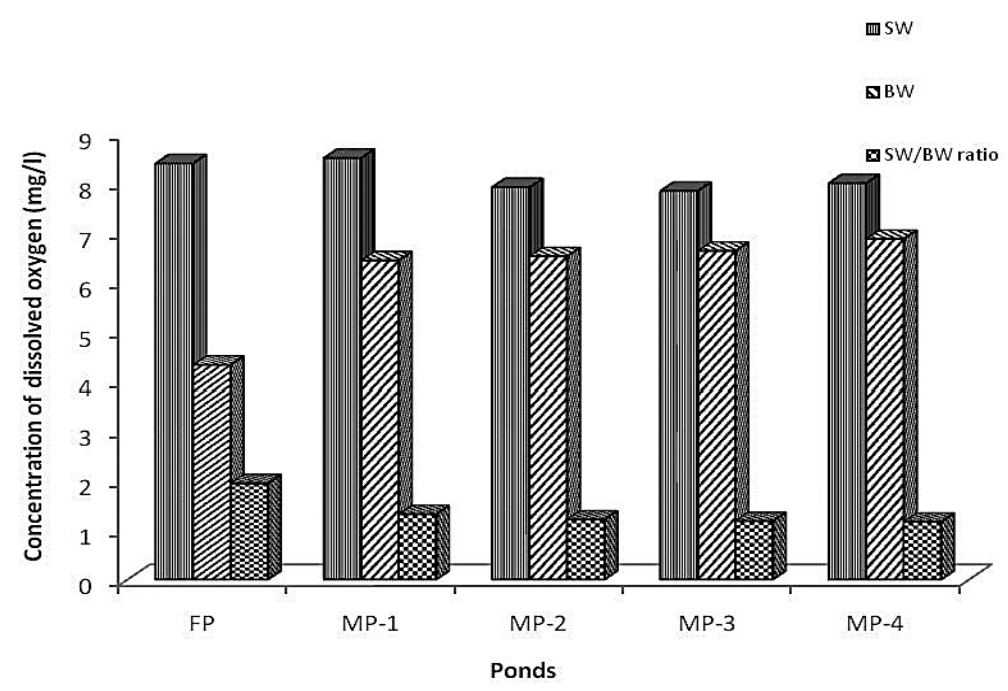

Figure 3. The overall mean concentration of dissolved oxygen of surface water (SW) and bottom water (BW) and their ratio along the sewage effluent gradient in different study ponds. Each mean represents the data for 24 observations during the period of 2 years

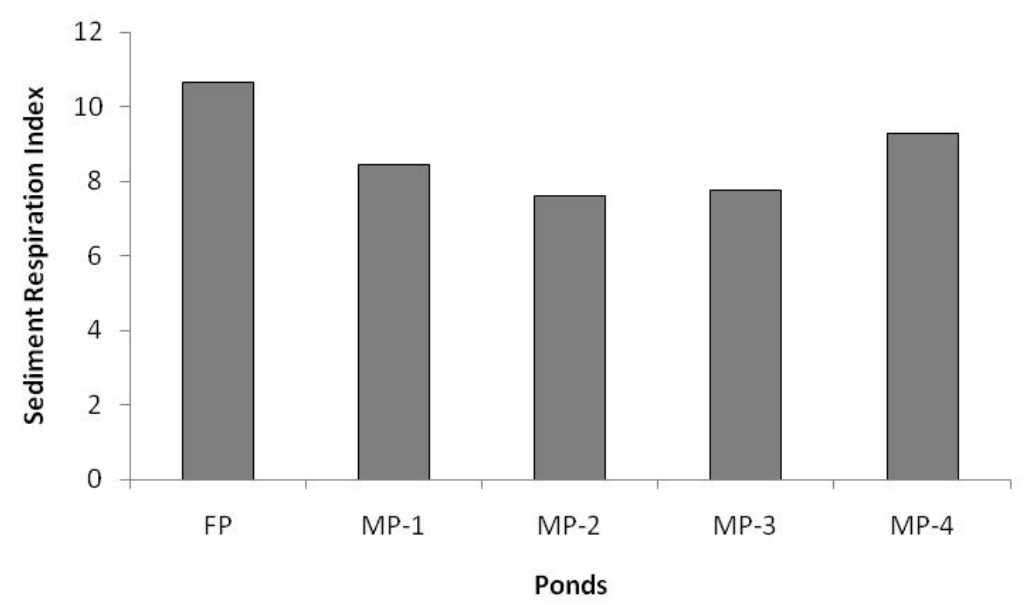

Figure 4. Sediment Respiration Index $\left(\mathrm{SR}_{\mathrm{I}}\right)$ in different ponds of waste stabilization pond system investigated

ponds investigated (Figure 7), and hence both of them reduced across the sewage effluent gradient. The concentration of chemical oxygen demand per unit of heterotrophic bacteria enumerated tended to rise gradually from facultative pond to maturation pond-3 followed by slight decline (Figure 8).

\section{DISCUSSION}

Ecological resilience of the waste stabilization pond system appeared to be maintained and enhanced by keystone structuring processes integrated with engineering resilience of constructed 


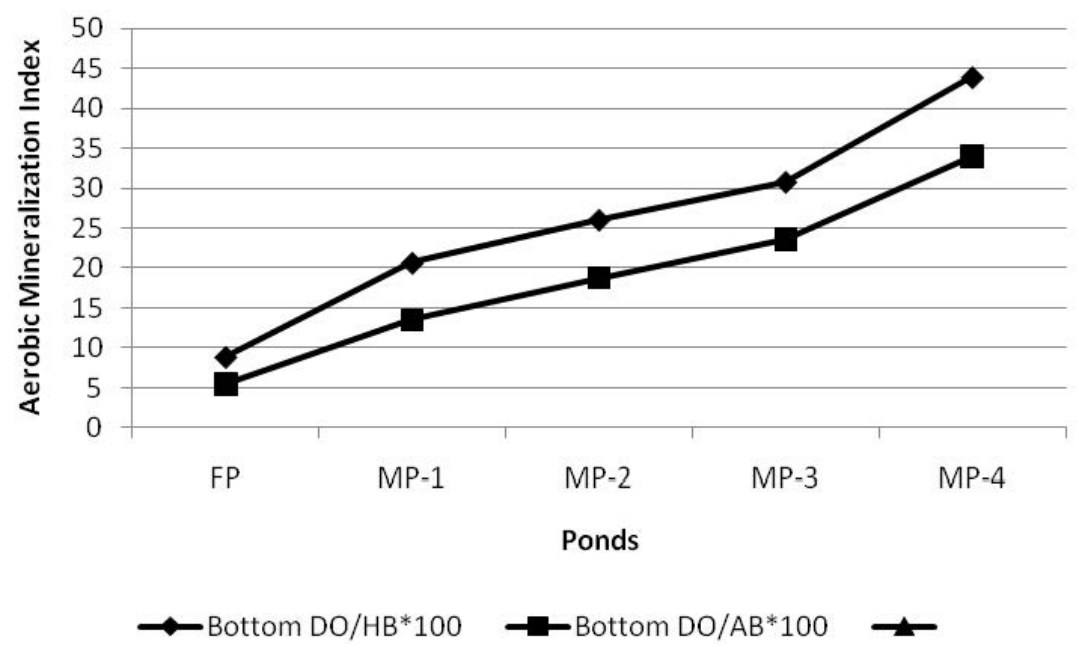

Figure 5. Aerobic Mineralization Index measured as aerobic degradation by heterotrophic bacteria and ammonifying bacteria in different ponds of waste stabilization pond system employed

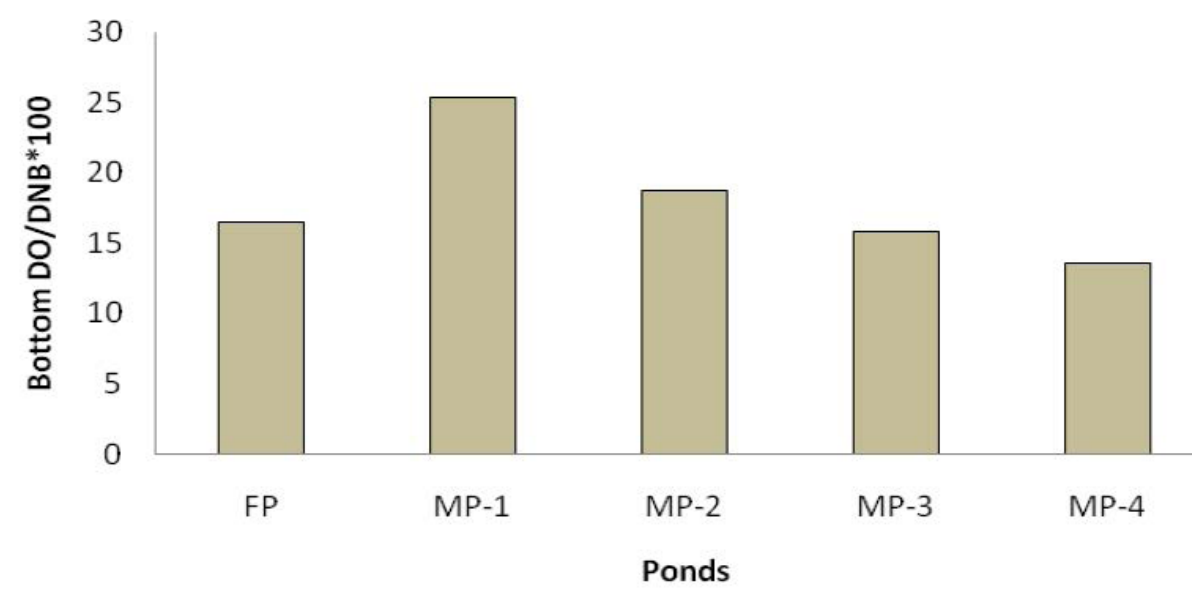

Figure 6. Oxygen demand by denitrifying bacteria measured as an index in different ponds as an inverse function of the sewage effluent in maturation ponds

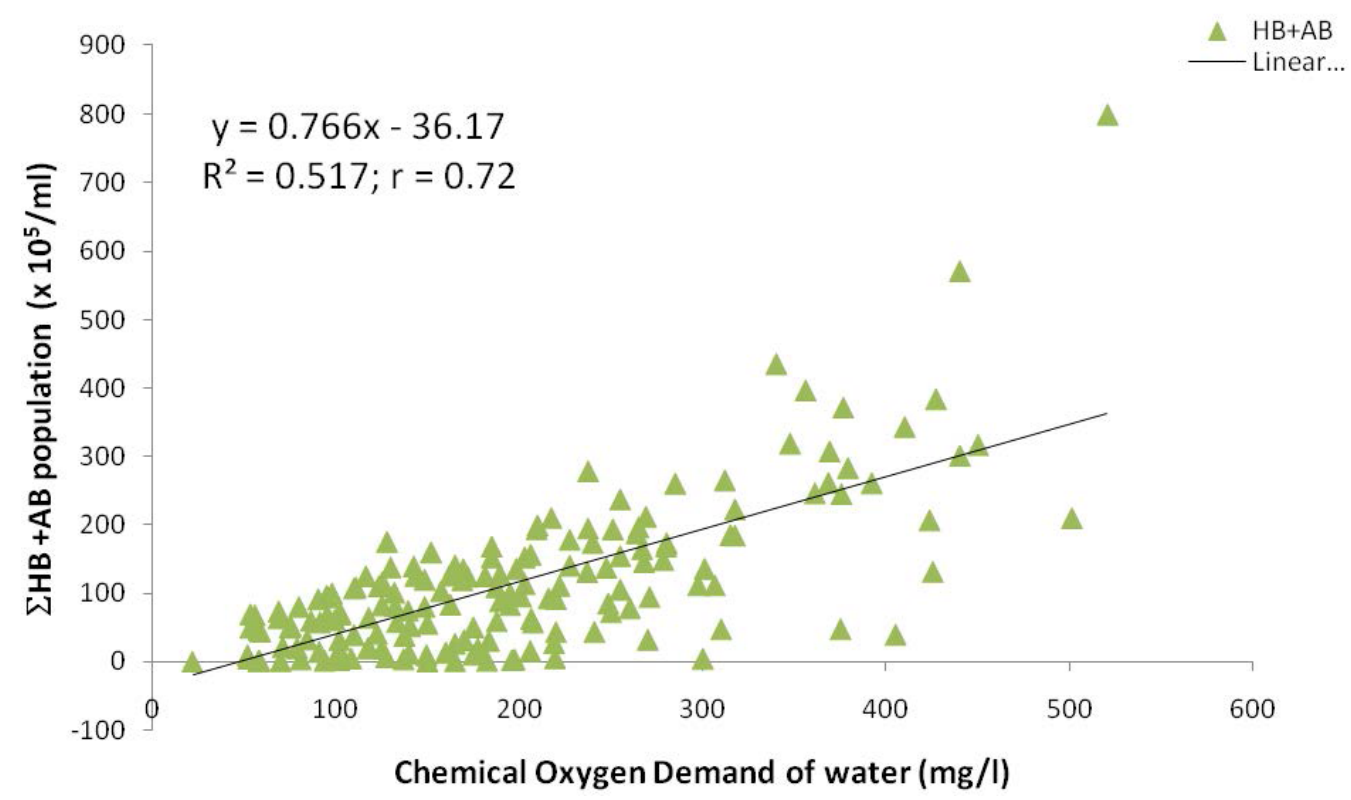

Figure 7. Relationship between sum total of heterotrophic and ammonifying bacterial population and chemical oxygen demand of surface water along the sewage effluent gradient of waste stabilization pond system. Data for 168 samples collected from six ponds during the period of 2 years were used 


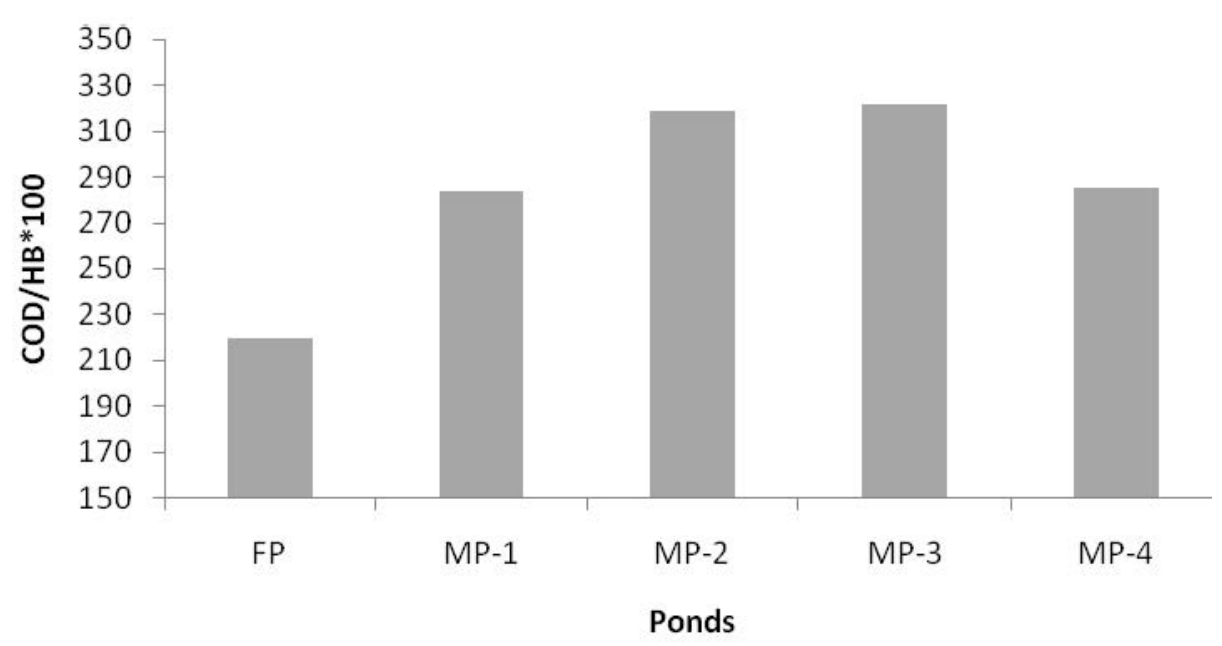

Figure 8. The rising trends of the ratio for chemical oxygen demand of water to heterotrophic bacteria in different ponds investigated

waste stabilization pond system having different structural configurations (anaerobic, facultative and maturation ponds) towards enhancing the functional resilience of the system. Further, redundancy hypothesis implicated that species redundancy enhanced the ecosystem resilience related to self organized behaviour of the ecosystems over time and space [Gunderson 2000]. The functional roles of the species would vary in a natural heterogenous environmental gradients [Wellnitz and LeRoy Poff, 2001].

It becomes evident that density of some major nutritional groups of bacteria (HB, $\mathrm{AB}$ and $\mathrm{PSB}$ ) tended to reduce across the sewage effluent gradient in all the compartments of the pond ecosystem resulting in reclamation of incoming sewage that has been quantified to be as high as $90 \%$ of its initial state in the existing waste stabilization ponds achieving the benign environment in the downstream of maturation ponds. This was exhibited by the gradual reduction in the concentrations of chemical oxygen demand of water from the facultative pond to the last maturation pond. However, the pattern of changes of oxygen dependent ammonia oxidizing bacteria (AOB) and cellulose decomposing bacteria (CDB) was related to the concentrations of dissolved oxygen of water from the inlet to the outlet of facultative pond. The results of aerobic mineralization index and sediment mineralization index revealed the pattern of changes consistent with ecological resilience of the system as a whole. While examining the relative abundance of three co-occurring species of damselfly co-varied differently along an environmental gradient of lake biotic and abiotic features consistent with ecological partitioning [Siepielski et al., 2011].
The stability and harmony of the ecosystem has finally been achieved by the redundancy of different subsystems as well as feedback mechanism of the system as a whole. The effective degradation and mineralization of organic matter was performed by the integral actions of microbial subsystem and oxygenation by the solar energy driven micro-algal subsystem reflecting as ecological signature for the entire reclamation process. The grazing pressure of zooplanktonbenthic animals-fish-heterotrophy complex interactions regulated the system mediated through feedback mechanism. The self-resiliency and self-purification of the system as well as physical processes of sedimentation and chelation also impacted in the process.

The performance of waste stabilization ponds was well recognized; the primary sedimentation tank and waste stabilization ponds have removed suspended solids by $45-60 \%$ and $80-95 \%$ of the initial load, respectively, whereas the corresponding values for BOD removal were 30-45\%, 7095\% and 90-97\% [Arceivala, 1970]. The direct relationship between the microbial load (heterotrophic and ammonifying) and chemical oxygen demand of water implied the reclamation of ecological processes occurred through heterotrophic microbial pathways.

Therefore, gradual spatial improvement in water quality across the sewage effluent gradient was the result of integrated, interacted, interdependent and coordinated activities of physical processes, sedimentation, chelation and microbial-algal-heterotroph-detritivores interactions.

Assessment of ecological signatures suggests that reclamation process and efficiency was not 
uniform across the sewage effluent gradient and was highly variable among the ponds of waste stabilization ponds despite the same trophic structure of the community. This clearly reflects the functional diversity in response to combination of interactive complex milieu. The specially designed facultative ponds were demonstrated to be most dynamic in the series because of major reclamation (42-62\%) of the whole system occurred in this subunit before being released into the next subunit of the whole process. This was attributed to the enhanced microbial activities and development of intense algal bloom which triggered the process of oxidation by solar radiation driven photosynthesis of micro-algae.

The autotrophic functional redundancy performed by 28 species of micro-algae perhaps represented an important aspect of reclamation of biological functionality along the sewage effluent gradient because of the fact that the diversity and abundance of phytoplankton were distinctly related with the total scores for all the optimal ecological conditions of the waste stabilization pond. It is stated that species may appear to perform the same function under a restricted set of conditions, yet their functional roles may vary in a natural heterogenous environments [Wellnitz and LeRoy Poff, 2001]. As is known spatial heterogeneity interacts with temporal disturbance to modify the relationship between species diversity and ecosystem productivity [Cardinale et al., 2000], seasonal distribution of phytoplankton community interacting with externalities of environment was responsible for the differences in carbon sequestration potentials of micro-algae between facultative and maturation ponds. This suggests that $\mathrm{CO}_{2}$ sequestration potential was not uniform throughout the sewage effluent gradient or throughout the year, but varied on temporal or time scale depending upon interactions between nutrient enrichment, water quality and species composition and photosynthetic efficiency of that particular group of phytoplankton community.

The sum of total scores for different optimal conditions for fish growth tended to increase as a function of the distance from the source of effluent (Figure 9) impacting upon the fish yield that increased steadily (34-66\%) from the first stocking pond to the last maturation pond. Further, the indicator of good fish health was variable and more accentuated in the last maturation pond. Using a stress marker respiratory enzyme in fish succinate dehydrogenase (SDH), Mukhrjee and Jana [2007] have shown significantly improved ecological condition prevailed in the last maturation pond impacting upon better fish health compared to facultative pond or first maturation pond.

In order to achieve maximal production of microbiologically safe fish with minimal treatment of wastewater, Mara et al. [1993] recommended retention time of effluent for one day in anaerobic and four day in facultative pond. However, in the present study, the time required for complete discharge of sewage water through the series of six

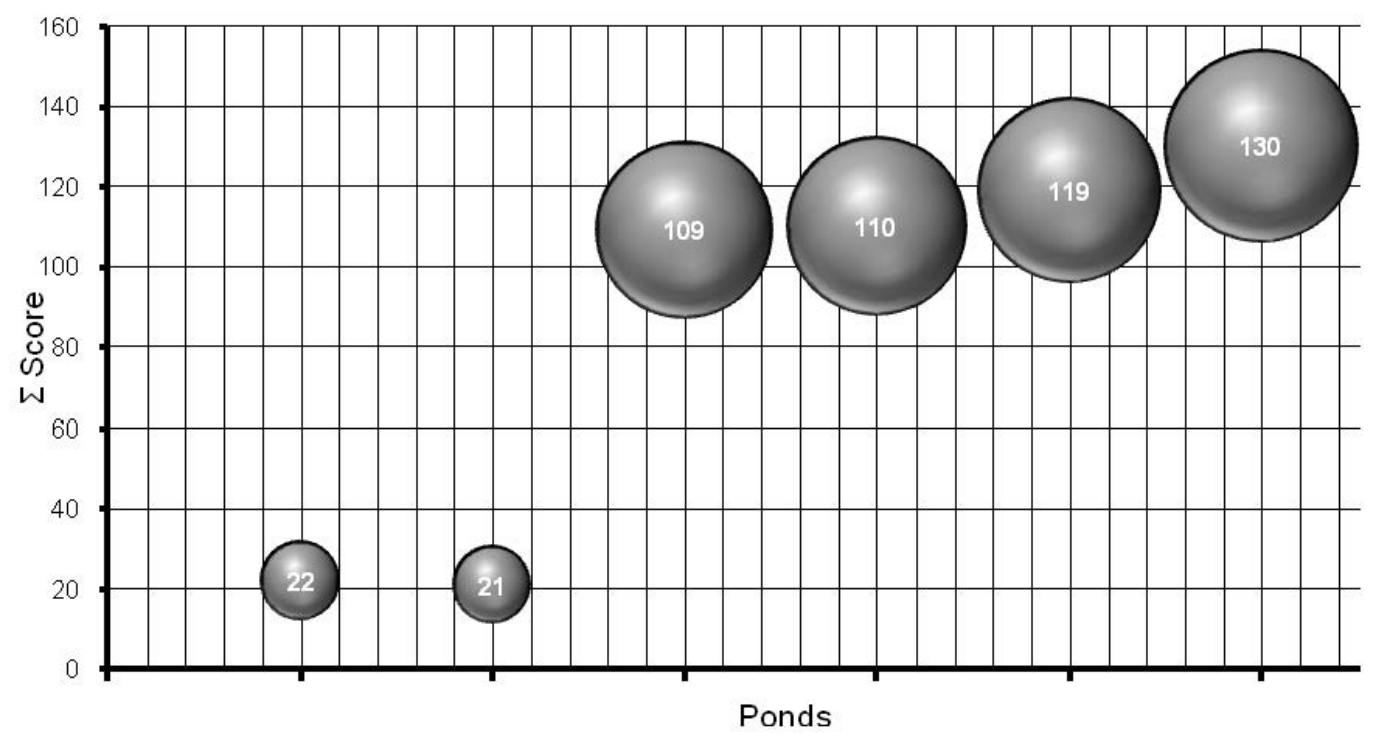

Figure 9. Total scores of optimal values of different parameters $(\Sigma \mathrm{pH}+$ dissolved oxygen + phosphate + +ammonium-N+nitrate-N+fish yield) plotted against six ponds along the sewage effluent gradient.

Total scores were obtained by summing up of the occurrence of all the optimal values out of 23 samples collected from each pond during the period of two years (2003-2005) 
ponds was about 12-14 days covering a distance of $400 \mathrm{~m}$ from the source of anaerobic pond. The stringent measure of longer retention time might be considered safe to ensure maximum reclamation of wastewater in the pond system before being discharged into the environment. Two distinct zones were well recognized along the sewage effluent gradient; the first one had greater carbon sequestration with dominance of blue green algae and the second one dominated with green algae developed in response to integrated actions for reclamation and served as food for fishes in maturation ponds.

\section{CONCLUSION}

It is, therefore, reasonable to conclude that the waste stabilization pond was primarily responsible for transforming organic wastes into fish biomass through the multichannel grazingdetritus-complex food-chain pathways. Anaerobic digestion of organic matter generated some intermediate toxic compounds which were later perhaps oxidized to non toxic end products when exposed to aerobic conditions of the stabilization ponds.

\section{Acknowledgements}

This research was supported from a grant (to BBJ) provided by the Indian Council of Agricultural Research, New Delhi.

\section{REFERENCES}

1. Alcocer-Durand J., Chavez-Arteaga M., EscobarBriones C., 1993. La Limnologiaen Mexico (historiay perspective future de las investigaciones limnologicas. Ciencia 44, 441-453.

2. American Public Health Association 2005. Standard methods for the examination of water and wastewater. $21^{\text {st }}$ ed. APHA, Washington, DC, NY.

3. Arceivala S.J., 1988. Wastewater treatment for pollution control. Tata McGraw Hill Publishing Company Limited, New Delhi, pp. 183.

4. Atlas R.M., Bartha R., 1998. Microbial ecology and applications. Benjamin/Cummings Science Publishing, California, pp. 694.

5. Cardinale B.J., Nelson K., Palmer M.A., 2000. Linking species diversity to the functioning of ecosystems: on the importance of environmental context. Oikos 9, 175-183.
6. Ganguly S. 2002. Some biogeochemical cycling bacteria and their activities as indicator of reclamation in tropical sewage fed fish farms. Ph.D Thesis Kalyani University, West Bengal, India.

7. Gunderson L.H., 2000. Ecological resilience- in theory and application. Annual Review of Ecological System 31, 425-439.

8. Holling C.S. 1973. Resilience and stability of ecological systems. Ann. Rev. of Ecol. Sys. 4, 1-23.

9. Jackson M.L., 1970. Soil Chemical Analysis. University of California.

10. Karlsson L., Liu X., Jewitt N., 2011. Waste stabilization/treatment ponds: Aerobic and anaerobic water treatment. Lund University, pp. 10.

11. Ludwig D., Walker B., Holling C.S. 1976. Sustainability, stability and resilence. Conser. Ecol. 1, $1-27$.

12. Mara D.D., Edwards P., Clark D., Mills S.W., 1993. A rational approach to the design of wastewaterfed fish pond. Wat. Res. 27(12), 1797-1799.

13. McMahon K.D., Read E.K., 2013. Microbial contributions to phosphorus cycling in eutrophic lakes and wastewater. Ann. Rev. of Micro. 67.

14. Mukherjee S., Jana B.B., 2007. Water quality affects SDH activity, protein content and RNA:DNA ratios in fish (Catla catla, Labeo rohita and Oreochromis mossambicus) raised in ponds of a sewage fed fish farm. Aquaculture 262, 105-119.

15. Odum, E.P., 1996. Basic Ecology. Saunders College Publication, Japan.

16. Siepielski A.M., Mertens A.N., Wilkinson B.L., McPeek M.A., 2011. Signature of ecological partitioning in the maintenance of damselfly diversity. J. of Ani. Ecol. 80, 1163-1173.

17. Sonthiphand P., Cejudo E., Schiff S.L., Neufeld J.D., 2013. Wastewater Effluent Impacts AmmoniaOxidizing Prokaryotes of the Grand River, Canada. Appl. and Environ. Micro. 79(23), 7454-7465.

18. Vollenweider R.A., 1974. A manual on methods for measuring primary production in aquatic environments. IBP. Blackwell Scientific Publications, Oxford, London.

19. Weaver J., Paquet P.C., Ruggiero L., 1996. Resilience and conservation of large carnivores in the Rocky mountains. Conser. Biol. 10, 964-976.

20. Wetzel R., Likens G.E., 1991. Limnologcal analyses. Second edition. Springer-Verlag, New York.

21. Wellnitz T., LeRoy Poff N., 2001. Functional redundancy in heterogenous environment: implications for conservation. Ecol. Lett. 4, 177-179.

22. Yin B., Crowley D., Sparovek G., Wanderley J.D.M., Borneman J., 2000. Bacterial functional redundancy along a soil reclamation gradient. Appl. Environ. Microbiol. 60, 4361-4365. 